\title{
Influence of Cultivation Method and Irrigation Regime on Growth, Oil Yield and Some Water Relations of Sage (Salvia officinalis, L.) in Heavy Clay Soils
}

\author{
Nahed, M. Rashed ${ }^{1}$ and E.A. Moursi ${ }^{2}$
}

\begin{abstract}
Two field experiments were established at Sakha Agricultural Research Station during the seasons of 2010 and 2011 to evaluate the effect of cultivation method (normal furrow and raisedbed cultivation on the two sides) and irrigation treatments (Traditional irrigation, irrigation with 0.8 Ep and irrigation by using ETP $=0.1642+0.8$ Ep Ibrahim equation) on the growth, oil yield and some water relations of sage plants. The obtained results showed that cultivation of sage on raisedbed was the best for producing taller plant with more branches, more number of leaves/plant, less leaves/stems ratio, heavier fresh and dry weight of herb as well as higher essential oil\% and essential oil yield/plant and for saving water of 1357.2 $\mathrm{m}^{3} /$ fed* than the normal furrows in the two cuts for both seasons. Traditional irrigation was effective in raising the productivity of herb, yield and essential oil. The interaction between the two treatments gave the best results. Concerning essential oil constituents cineol was the major compound followed by Myrcene, Thujon was the third component. The values of applied irrigation water, the used consumptive water, irrigation water productivity and productivity of irrigation water were clearly affected by cultivation method and irrigation treatments. So, it could be recommended to cultivate sage on raisedbed at the two sides and irrigate with traditional irrigation using approximately $3345.1 \mathrm{~m}^{3}$ Water /fed to obtain the best growth parameter and oil yield of Salvia officinalis L. plant cultivated in heavy clay soil.
\end{abstract}

$*$ fed $($ Feddan $)=4200 \mathrm{~m}^{2}$

Keywords: Salvia officinalis, cultivation method, irrigation regime, essential oil, oil yield, water productivity, the used consumptive water, water applied and productivity of irrigation water.

\section{INTRODUCTION}

In Egypt, water is the most critical factor in crop production. Rainfall is low with erratic distribution. Therefore, almost agricultural production is mainly dependent upon irrigation or so-called irrigated agriculture. Water resources are concentrated on the Nile River and sometimes groundwater. The Egyptian water budget from the Nile is 55.5 milliard cubic meter. Under limitation of fresh water resource the farmers will have to use other resources in irrigation such as groundwater with a good quality. The main problem for using this source is the high lifting expenses particularly from deep levels. Because of the water limitation faces Egypt, we should be done our best towards effective rationalization of irrigation on a farm level.

The present share of water in Egypt is less than 1000 $\mathrm{m}^{3} /$ capita/year which is equivalent to the international standards of water poverty limit (El-Quosy, 1998). Irrigation is the main sector in water demand at the national level. Water allocated to irrigation is about $85 \%$ from the total renewable water. So, effective water management at the irrigation sector is the principal way towards the rationalization policy for the country. In this aspect, effective on farm irrigation management becomes a must.

Salvia officinalis L. (Sage) from the Latin "Salvere", meaning heal or save indicating the medical value of the plant, belongs to family Lamiaceae, it is perennial herb native to southern Europe and Asia Minor (Huxley, 1992). It has been used for a variety of disorders including respiratory infections, menstrual difficulties and digestive complaints. It was also believed to strength the sense of memory. The leaves of $S$. officinalis are used to relive headache, flatulence, toothache, abdominal pain, and common cold or as a sedative agent, wound healing and antidiabetic preparation (Al-Qura'n, 2009). Several studies have been published indicating the antioxidant and antimicrobial properties of essential oils extracted from S. officinalis. The principal constituents of essential oil are thujone, cineol, carophyllene and other terpenes .

Cultivation method considers one of the effective means for rationalization of irrigation water. Raisedbed may allow to save irrigation water and still maintain satisfactory levels of production .Therefore, there is an urgent need to improve irrigation water management for local farmers

Tremendous efforts should be implemented towards the aim of such effective water management at the farm level. Some of these efforts include: (1) determination of irrigation water which should be applied and (2) the use of raisedbed for furrow crops. Making rationalization for watering of medicinal and aromatic plants is becoming in a bad need because there aren't enough information about its water requirements and

\footnotetext{
${ }^{1}$ Department of Medicinal and Aromatic Plants, Agric. Res. Center, Dokki, Giza, Egypt.

${ }^{2}$ Soil, Water and Environment Res. Inst., Agric. Res. Center,

Giza, Egypt.

Received July14, 2012, Accepted August 28,, 2012
} 
consumptive use. Investigation watering behavior of these plants will be urgent in the near future because there is excess in its irrigation (Nadjafi et al., 2006 and Bannayan et al., 2008).

From the previously mentioned review of literature, it could be observed that irrigation had an effective role on the growth and yield of the study plants. This investigation aimed to study the rationalization of Salvia officinalis, L. irrigation water by cultivation on raisedbed, investigation the water behaviour of the crop under the condition of the studied site and studying the interaction effect between cultivation method and irrigation treatments on the growth, oil yield and components and some water relations.

\section{MATERIALS AND METHODS}

This investigation was conducted at the Experimental Farm of Sakha Agricultural Research Station, Kafr El-Sheikh Governorate. The site is located at $3107 \mathrm{~N}$ latitude, $3057 \mathrm{E}$ longitude with an elevation of about 6 meters above mean sea level. This location is a representative of conditions in the middle Northern Part of Nile Delta region during the two successive growth season

s of 2010 and 2011 to study the influence of cultivation method and irrigation regime on growth and oil yield of sage (Salvia officinalis L.) plants. Seedling of sage were obtained from Medicinal and Aromatic plants Department, ARC, Egypt ,In mid-March during

Table A. The mean values of some chemical properties of the experimental site before transplanting of Salvia officinalis $\mathrm{L}$. in the two growing seasons (2010 and 2011)

\begin{tabular}{|c|c|c|c|c|c|c|c|c|c|c|c|}
\hline \multirow{2}{*}{$\begin{array}{c}\text { Soil } \\
\text { depth, cm }\end{array}$} & \multicolumn{2}{|c|}{ EC mmhos/ Suspension soil } & \multirow[t]{2}{*}{ SAR } & \multicolumn{4}{|c|}{ Cations meq/ 1} & \multicolumn{4}{|c|}{ Anions meq/ l } \\
\hline & $\mathrm{n} \mathrm{cm}$ at $25^{\circ} \mathrm{C}$ & $1: 2: 5 \mathrm{pH}$ & & $\mathbf{C a}^{++}$ & $\mathrm{Mg}^{++}$ & $\mathrm{Na}^{+}$ & $\mathbf{K}^{+}$ & $\mathrm{CO}_{3}^{--}$ & $\mathrm{HCO}_{3}^{-}$ & $\mathrm{Cl}^{-}$ & $\mathrm{SO}_{4}^{--}$ \\
\hline $0-15$ & 2.10 & 8.1 & 3.79 & 6.4 & 5.1 & 9.1 & 0.46 & 0.0 & 3.3 & 10.1 & 7.86 \\
\hline $15-30$ & 2.10 & 8.1 & 5.85 & 5.0 & 4.0 & 12.4 & 0.37 & 0.0 & 6.5 & 13.2 & 2.07 \\
\hline $30-45$ & 2.65 & 8.1 & 6.13 & 5.0 & 6.5 & 14.7 & 0.34 & 0.0 & 5.1 & 12.9 & 8.54 \\
\hline $45-60$ & 2.30 & 8.1 & 5.71 & 4.6 & 5.4 & 12.8 & 0.36 & 0.0 & 5.0 & 12.1 & 6.06 \\
\hline
\end{tabular}

$\mathrm{SO}_{4}^{--}$was estimated by difference

Table B. The mean values of some physical properties of the experimental site before transplanting of Salvia officinalis L. in the two growing seasons (2010 and2011)

\begin{tabular}{|c|c|c|c|c|c|c|c|c|c|c|}
\hline \multirow{2}{*}{$\begin{array}{l}\text { Soil depth } \\
\text { (cm) }\end{array}$} & \multicolumn{4}{|c|}{ Particle size distribution } & \multirow{2}{*}{$\begin{array}{l}\text { Texture } \\
\text { class }\end{array}$} & \multirow{2}{*}{$\begin{array}{c}\text { F.C } \\
\%\end{array}$} & \multirow{2}{*}{$\begin{array}{c}\text { PWP } \\
\%\end{array}$} & \multirow[t]{2}{*}{$\mathrm{Bd} \mathrm{Mg} / \mathrm{m}^{3}$} & \multirow{2}{*}{$\begin{array}{c}\text { AW } \\
\%\end{array}$} & \multirow{2}{*}{$\begin{array}{c}\% \\
\text { Total } \\
\text { porosity }\end{array}$} \\
\hline & $\begin{array}{l}\text { Coarse } \\
\text { sand \% }\end{array}$ & $\begin{array}{c}\text { fine sand } \\
\%\end{array}$ & $\begin{array}{c}\text { Silt } \\
\%\end{array}$ & $\begin{array}{c}\text { Clay } \\
\%\end{array}$ & & & & & & \\
\hline $0-15$ & 1.60 & 13.00 & 16.50 & 68.90 & Clayey & 45.13 & 24.53 & 1.14 & 20.6 & 56.98 \\
\hline $15-30$ & 1.80 & 12.99 & 26.20 & 59.01 & Clayey & 43.00 & 23.37 & 1.24 & 19.63 & 53.21 \\
\hline $30-45$ & 2.20 & 13.60 & 27.50 & 56.70 & Clayey & 41.27 & 22.43 & 1.29 & 18.84 & 51.32 \\
\hline $45-60$ & 2.40 & 13.97 & 29.03 & 54.60 & Clayey & 39.48 & 21.46 & 1.33 & 18.02 & 49.81 \\
\hline
\end{tabular}

$\mathrm{FC}=$ Soil field capacity $(\%), \quad \mathrm{PWP}=$ Permanent wilting point $(\%)$

$\mathrm{Bd}=$ Soil bulk density $\left(\mathrm{Mg} / \mathrm{m}^{3}\right), \quad \mathrm{AW}=$ Soil available water $(\%)=(\mathrm{F} \cdot \mathrm{C}-\mathrm{PWP})$

Total porosity $(\%)=\frac{\text { Real density }- \text { Bulk density }}{\text { Real density }} \times 100$

Real density in mineral soils $=2.65 \mathrm{Mg} / \mathrm{m}^{3}$ the two seasons. Seedling of 2-3 pairs of leaves were transplanted in heavy clayed soil. The chemical properties of the studied soil were determined before cultivation process according to Black et al. (1965) are shown in Table (A) and physical properties such as soil permanent wilting point (PWP) and soil available water (AW) were determined according to James (1988) and soil bulk density were determined according to Vomocil (1957). The particle size distribution were determined according to the international method (Klute, 1986) to the soil texture was carried out in The Soil and Water Lab (ARC) are shown in Table (B). The plot area was $63 \mathrm{~m}^{2}$ (7 m width $\times 9 \mathrm{~m}$ length) and the experimental design was split plot with three replications. The main plots were randomly assigned by cultivation methods (traditional cultivation on furrows with width $70 \mathrm{~cm}$ apart and the distance between each hill was about 30 $\mathrm{cm}$ apart on one side and cultivation on raisedbed with width $140 \mathrm{~cm}$ apart and the distance between each hill was about $30 \mathrm{~cm}$ apart on the two sides (300 plant/plot for each treatment)). The sub-plots were irrigation treatments (traditional irrigation like local farmers "control", irrigation with 0.8 Ep and irrigation by using Ibrahim equation (1981) which is empirical for the central Nile Delta region ETP $=0.1642+0.8 \mathrm{Ep} \mathrm{cm} /$ day where $\mathrm{ETP}=$ potential evapotranspiration $\mathrm{cm} / \mathrm{day}$, Ep= Pan evaporation $\mathrm{cm} /$ day). 
Mineral fertilizations at the recommended dose of $150 \mathrm{~kg}$ ammonium sulphate $(20.5 \% \mathrm{~N}), 150 \mathrm{~kg}$ calcium monophosphate $\left(15.5 \% \quad \mathrm{P}_{2} \mathrm{O}_{5}\right)$ and $50 \mathrm{~kg}$ potassium sulphate $\left(48 \% \quad \mathrm{~K}_{2} \mathrm{O}\right)$ per feddan were added after 45 days from transplanting and after $1^{\text {st }}$ cut in the two seasons.

Sage herb was harvested twice, the first cut on August $1^{\text {st }}$ and the second on $1^{\text {st }}$ November in the both seasons. At harvest stage the following data were recorded per plant:

1)Plant height $(\mathrm{cm})$

2)Number of main branches/plant

3)Number of leaves/plant

4)Leaves/stems ratio

5)Herb fresh and dry weight ( $\mathrm{g} / \mathrm{plant}$ )

6)Essential oil percentage was determined in dry herb according to British pharmacopoeia (1963)

7)Oil yield per plant was determined and then calculated

8)Essential oil constituents: GC/mass analysis of volatile oil of each treatment was performed with specification of the apparatus used according to Robert (1995).

\section{Irrigation measurements:}

\section{1) Applied irrigation water:}

The irrigation flow rate per plot was calculated according to Israelsen and Hansen equation (1962)

$$
q=0.0226 \mathrm{D}^{2} h^{1 / 2}
$$

Where: $\mathrm{q}=$ irrigation flow rate $\mathrm{cm}^{3} / \mathrm{sec}$

$\mathrm{h}=$ Average effective head and

$\mathrm{D}=$ Inside diameter of the pipe, $\mathrm{cm}$,

The amount of water applied for each plot was calculated by using this formula

$$
\mathrm{a}=\mathrm{q} * \mathrm{~T}
$$

Where: $\quad \mathrm{a}=$ Water volume/plot $\left(\mathrm{m}^{3}\right)$

$\mathrm{q}=$ Irrigation flow rate $\left(\mathrm{cm}^{3}\right)$

$\mathrm{T}=$ Total recorded time for each plot (min.)

\section{2) Irrigation water efficiencies $\left(\mathrm{kg} / \mathrm{m}^{3}\right)$}

2.1 Water productivity (WP) and productivity of irrigation water (PIW)

Water productivity (PW) and Productivity of irrigation water (PIW) was calculated according to (Ali et al, 2007):

$$
\mathrm{PW}=\mathrm{Y} / \mathrm{Cu} \text { and } \mathrm{PIW}=\mathrm{Y} / \mathrm{Wa}
$$

Where: $\mathrm{PW}=$ water productivity $\left(\mathrm{kg} \mathrm{m}^{-3}\right)$

$\mathrm{Cu}=$ the used consumptive water $\left(\mathrm{m}^{3} \mathrm{fed}^{-1}\right)$

$\mathrm{PIW}=$ productivity of irrigation water $\left(\mathrm{kg} / \mathrm{m}^{3}\right)$

$$
\begin{aligned}
\mathrm{Y} & =\text { Marketable yield }(\mathrm{kg} / \mathrm{fed} .) \\
\mathrm{Wa} & =\text { Water applied, } \mathrm{m}_{3} / \mathrm{fed} .
\end{aligned}
$$

\section{3) The used consumptive water (CU)}

The used consumptive water by growing plants was calculated based on soil moisture depletion (SMD) according to Hansen et al. (1979).

$$
\mathrm{CU}=\mathrm{SMD} \sum_{\mathrm{i}=1}^{\mathrm{i}=4} \frac{\mathrm{PW}_{2}-\mathrm{PW}_{1}}{100} * \mathrm{Dbi} * \mathrm{Di}
$$

Where: $\mathrm{CU}=$ The used consumptive water $(\mathrm{cm})$ in the effective

root zone $(60 \mathrm{~cm})$.

$\mathrm{PW}_{2}=$ Gravimetric soil moisture percentage after irrigation.

$\mathrm{PW}_{1}=$ Gravimetric soil moisture percentage before irrigation.

Dbi= Soil bulk density $\left(\mathrm{mg} / \mathrm{m}^{3}\right)$ for depth.

$\mathrm{Di}=$ Soil layer depth $(15 \mathrm{~cm})$.

$1=$ Number of soil layers (1-4)

Data of both seasons were tabulated and statistically analyzed according to procedure described by Steel and Torrie (1980) and differences between the means were compared by Duncan's Multiple Range Test as Snedecor and Cochran (1967) using MSTAT-C computer program.

\section{RESULTS AND DISCUSSION}

\section{Plant height and number of main branches/plant:}

Data in Table (1) indicated that cultivation method and/or irrigation treatments had significant effect on plant height and number of main branches/plant in each cut of both seasons. Plant height and number of main branches increased under raisedbed in comparison with normal furrow wide in the two cuts for the both seasons. These results may be due to the more suitable unit area for roots and plant growth and more suitable amount of light in case of raisedbed, compared to normal furrows in heavy clay soils. These results are similar to those obtained by El-Boraie and Gaber (2009) and El-Boraie et al. (2009) on roselle they found that plant height and number of branches/plant were significantly increased by increasing the plant density.Meanwhile, Ghaly, et al .(2003) on Carum Carvi ,L. showed that vegetative growth significantly increased with sowing plants at one side of the ridge.

Plant height and number of main branches/plant were affected by irrigation treatments. The highest mean values were recorded under control treatments (traditional irrigation) in comparison with other irrigation treatments. The mean values of the two studied parameters can be descended in order traditional 
Table 1. Effect of cultivation method and irrigation treatments on plant height $(\mathrm{cm})$ and number of main branches/plant of Salvia officinalis L. herb during the two seasons (2010 and 2011)

\begin{tabular}{|c|c|c|c|c|c|c|c|c|c|c|c|c|}
\hline \multirow[b]{3}{*}{ Treatments } & \multicolumn{6}{|c|}{ Plant height (cm) } & \multicolumn{6}{|c|}{ Number of main branches/plant } \\
\hline & \multicolumn{3}{|c|}{$1^{\text {st }}$ cut } & \multicolumn{2}{|c|}{$2^{\text {nd }}$ cut } & \multirow[b]{2}{*}{ Mean } & \multicolumn{3}{|c|}{$1^{\text {st }}$ cut } & \multicolumn{2}{|c|}{$2^{\text {nd }}$ cut } & \multirow[b]{2}{*}{ Mean } \\
\hline & $\begin{array}{l}\text { Normal } \\
\text { furrow }\end{array}$ & $\begin{array}{c}\text { Rasied } \\
\text { bed }\end{array}$ & Mean & $\begin{array}{l}\text { Normal } \\
\text { furrow }\end{array}$ & $\begin{array}{c}\text { Rasied } \\
\text { bed }\end{array}$ & & $\begin{array}{l}\text { Normal } \\
\text { furrow }\end{array}$ & $\begin{array}{c}\text { Rasied } \\
\text { bed }\end{array}$ & Mean & $\begin{array}{l}\text { Normal } \\
\text { furrow }\end{array}$ & $\begin{array}{c}\text { Rasied } \\
\text { bed }\end{array}$ & \\
\hline & \multicolumn{12}{|c|}{$1^{\text {st }}$ Season 2010} \\
\hline I1 & $87.97 \mathrm{a}$ & $98.33 \mathrm{a}$ & $93.00 \mathrm{a}$ & $75.00 \mathrm{~d}$ & $84.67 \mathrm{~b}$ & $79.83 \mathrm{a}$ & $12.67 \mathrm{~b}$ & $12.00 \mathrm{~b}$ & $12.33 \mathrm{a}$ & $15.33 \mathrm{~b}$ & $17.00 \mathrm{a}$ & $16.17 \mathrm{a}$ \\
\hline $\mathbf{I} 2$ & $79.67 \mathrm{a}$ & $90.00 \mathrm{a}$ & $84.83 \mathrm{~b}$ & $61.33 \mathrm{f}$ & $76.33 \mathrm{c}$ & $68.83 \mathrm{c}$ & $7.00 \mathrm{~d}$ & $12.33 \mathrm{~b}$ & $9.67 \mathrm{~b}$ & $9.33 \mathrm{c}$ & $14.67 \mathrm{~b}$ & $12.00 \mathrm{~b}$ \\
\hline I3 & $80.67 \mathrm{a}$ & $91.67 \mathrm{a}$ & $86.17 \mathrm{~b}$ & $65.67 \mathrm{e}$ & $86.00 \mathrm{a}$ & $75.83 \mathrm{~b}$ & $9.67 \mathrm{c}$ & $13.67 \mathrm{a}$ & $11.67 \mathrm{a}$ & $15.33 \mathrm{~b}$ & $15.33 \mathrm{~b}$ & $15.33 \mathrm{a}$ \\
\hline \multirow[t]{2}{*}{ Mean } & $93.33 \mathrm{a}$ & $82.67 \mathrm{a}$ & & $67.33 b$ & $82.33 \mathrm{a}$ & & $9.78 b$ & $12.67 \mathrm{a}$ & & $13.33 \mathrm{~b}$ & $15.67 \mathrm{a}$ & \\
\hline & \multicolumn{12}{|c|}{$2^{\text {nd }}$ Season 2011} \\
\hline I1 & $72.67 \mathrm{~b}$ & $77.00 \mathrm{a}$ & $74.83 \mathrm{a}$ & $58.00 \mathrm{~b}$ & $65.00 \mathrm{a}$ & $61.50 \mathrm{a}$ & $7.33 \mathrm{~d}$ & $9.33 \mathrm{a}$ & $8.33 \mathrm{a}$ & $10.33 \mathrm{a}$ & $9.67 \mathrm{~b}$ & $10.00 \mathrm{a}$ \\
\hline $\mathbf{I 2}$ & $53.33 \mathrm{e}$ & $62.33 \mathrm{~d}$ & $57.83 \mathrm{c}$ & $44.67 \mathrm{e}$ & $51.67 \mathrm{~d}$ & $48.78 \mathrm{~b}$ & $4.33 \mathrm{e}$ & $7.67 \mathrm{c}$ & $6.00 \mathrm{~b}$ & $5.33 \mathrm{~d}$ & $9.33 \mathrm{bc}$ & $7.33 \mathrm{~b}$ \\
\hline $\mathbf{I 3}$ & $65.33 \mathrm{c}$ & $75.00 \mathrm{a}$ & $70.17 \mathrm{~b}$ & $54.33 \mathrm{c}$ & $63.33 \mathrm{a}$ & $58.83 \mathrm{a}$ & $9.00 \mathrm{~b}$ & $7.33 \mathrm{~d}$ & $8.17 \mathrm{a}$ & $9.00 \mathrm{c}$ & $10.67 \mathrm{a}$ & $9.83 \mathrm{a}$ \\
\hline Mean & $63.78 b$ & $71.44 \mathrm{a}$ & & $52.33 \mathrm{~b}$ & $60.00 \mathrm{a}$ & & $6.89 \mathrm{a}$ & $8.11 \mathrm{a}$ & & $8.22 \mathrm{~b}$ & $9.89 \mathrm{a}$ & \\
\hline
\end{tabular}

In the same cell means followed by the same letter are not significantly different at 5\% level according to Duncan Multiple Range Test

$\mathrm{I}_{1}$ : Traditional irrigation (control), $\mathrm{I}_{2}$ : Irrigation with $0.8 \mathrm{Ep}, \mathrm{I}_{3}$ : Irrigation by using Ibrahim equation.

irrigation $\left(\mathrm{I}_{1}\right)>$ Ibrahim equation $\left(\mathrm{I}_{3}\right)>$ irrigation with $0.8 \mathrm{Ep}\left(\mathrm{I}_{2}\right)$ in the two cuts of the both seasons. These results may be due to the effect of the used amount of traditional irrigation on increasing the growth of root system, consequently, increasing the nutrients uptake needed for plant growth, besides enhancing the rates of physiological processes and increasing the hydrostatic pressure on the cell wall, which is necessary for the enlargement of cell. Hence, enhancement of assimilated food and increase cell elongation and division consequently, the whole growth of plant could be increased. These results are in agreement with that of Khattab et al. (2002) on Salvia splendens, El- Mekawy (2009) on Thymus capitatus and Farahani et al. (2009) on Melissa officinalis L. they found that longest plants were achieved under $\mathrm{T}_{1}(100 \%$ field capacity).

In each cut of both seasons the interaction between cultivation method and irrigation treatments gave significantly increases of the plant height and number of main branches of Salvia officinalis L plants. The longest plant height was obtained from the treatment of combined with (raisedbed and Ibrahim equation irrigation $\mathrm{I}_{3}$ ) in both cut of the two growing seasons. Where the biggest number of main branches were obtained from the treatment of (raisedbed and Ibrahim equation irrigation $\mathrm{I}_{3}$ ) in the first cut of the first season and $2^{\text {nd }}$ cut in the second season and (raisedbed and traditional irrigation) in the $2^{\text {nd }}$ cut for the first season and $1^{\text {st }}$ cut in the second season, respectively. These results reflect the importance of cultivation method and irrigation for stimulating the growth of sage plants. Similar results were obtained by El- Mekawy (2009) on
Thymus capitatus who showed that the short irrigation interval every 10 days was the best for producing taller plants with more branches than the long intervals every 20 and 30 days.

\section{Number of leaves/plant and leaves/stems ratio:}

The reported data in Table (2) clearly showed that the number of leaves/plant and leaves/stems ratio were significantly increased by cultivation method i.e. cultivation on raisedbed recorded the highest mean values for number of leaves/plant in the first season of both cut on contrary cultivation on normal furrows recorded the highest mean value in the second season of both cut and the highest leaves/stems ratio in both seasons of the two cut.These results may be due to cultivation on raisedbed increased plant height and number of branches/plant of Salvia officinalis L. Where this reflect on lowest number of leaves/plant and leaves/stems ratio as compared with cultivation on normal furrows. These results indicated that individual plants of this species produced more branches and shoot growth at raisedbed to compensate for the lower number of plants per unit which was reported by other investigation; Nadjafi et al. (2006) on Ferula gummosa and Teucrium polium and Khazaie et al. (2008) on Thyme and hyssop.

The highest values of number of leaves/plant were obtained by traditional irrigation $\left(\mathrm{I}_{1}\right)$ in the two cuts for both seasons. Otherwise, irrigation at $0.8 \mathrm{Ep}\left(\mathrm{I}_{2}\right)$ recorded the highest values of leaves/stems ratio in both cuts of the two seasons. These results may be due to irrigation at 0.8 pan evaporation may be improved leaves/stems ratio which increase in the availability of 
water per plant and enhancing cell division and cell enlargement. Similar results are obtained by Katsoulas et al. (2006) who studied the effect of irrigation frequency on production and quality of rose (Rosa hybrida, cv. First Red) flowers and found that high irrigation frequency improved biomass production but did not affect the quality of harvested flowers.

Cultivation on normal furrows combined with traditional irrigation $\left(\mathrm{I}_{1}\right)$ gave the highest significant values of number of leaves/plant in both cuts in the two seasons, while cultivation on normal furrows with irrigation at $0.8 \mathrm{Ep}\left(\mathrm{I}_{2}\right)$ gave the highest significant values of leaves/stems ratio in both cuts in the two seasons. These results are in agreement with those obtained by Younis et al. (2010) on fennel they found that decreasing irrigation levels increased the production of fennel and the optimum irrigation levels for the highest vegetative growth was $40 \%$ from available soil water.

\section{Fresh and dry weight of herb (g):}

Cultivation on raisedbed gave the highest values of fresh and dry weight/plant in most cases in the two cuts of the both seasons Table(3). This may be due to the raisedbed encouraged the whole growth of the plants by supplying the plant with the favourable moisture conditions which the crop covered the ground at a faster rate and developed sufficient photosynthetic area needed for maximum utilization of solar radiation. Similar results were reported in the case of Singh et al. (2002) on patchouli.

Data in Table (3) cleared that traditional irrigation $\left(\mathrm{I}_{1}\right)$ and irrigation by using Ibrahim equation $\left(\mathrm{I}_{3}\right)$ gave the highest values for fresh and dry weight/plant without significant differences in most cases for both cuts in the two seasons, comparing to the other treatments which obtained the lowest values of fresh and dry weight/plant. These results may be due to the importance role of water availability on increasing the biosynthates accumulated, consequently increased the dry matter of herb. Similar trends of results are obtained by Ahmetozlurk et al. (2004) on Melissa officinalis who found that dry yield under water deficit varied from 13.05 to $19.20 \mathrm{~g}$ per plant.

Cultivation on raisedbed combined with traditional irrigation $\left(\mathrm{I}_{1}\right)$ gave the highest values of fresh and dry weight/plant in the two cuts of the first season where in the second season the highest values of fresh weight obtained from the treatment of (raisedbed combined with Ibrahim equation irrigation $\mathrm{I}_{3}$ ) and the highest dry weight obtained from (normal furrow combined with traditional irrigation $I_{1}$ ). Similar results are found by ElBoraie and Gaber (2009) on roselle.

\section{Essential oil\% and essential oil yield (L/plant):}

Data in Table (4) illustrated that cultivation method and/or irrigation treatments hadnot significant effect on essential oil \% and oil yield/plant.Similarly, Ghaly, et al .(2003) on Carum Carvi ,L. found that essential oil \% wasnot affected by sowing method . the highest values of the essential oil yield/plant in the dry herb were obtained from plants irrigated with traditional irrigation $\left(\mathrm{I}_{1}\right)$ and irrigation by using Ibrahim equation $\left(\mathrm{I}_{3}\right)$ without any significant difference between them in most cases in the two cuts for both seasons. The interaction between using cultivation method and irrigation treatment were not significant for essential oil \% and significant for oil yield/plant in the two cuts for both seasons.

Table 2. Effect of cultivation method and irrigation treatments on number of leaves/plant and leaves/stems ratio of Salvia officinalis L. herb during the two seasons (2010 and 2011)

\begin{tabular}{|c|c|c|c|c|c|c|c|c|c|c|c|c|}
\hline \multirow[b]{3}{*}{ Treatments } & \multicolumn{6}{|c|}{ No of leaves/plant } & \multicolumn{6}{|c|}{ Leaves/stem ratio } \\
\hline & \multicolumn{3}{|c|}{$1^{\text {st }}$ cut } & \multicolumn{2}{|c|}{$2^{\text {nd }}$ cut } & \multirow[b]{2}{*}{ Mean } & \multicolumn{3}{|c|}{$1^{\text {st }}$ cut } & \multicolumn{2}{|c|}{$2^{\text {nd }}$ cut } & \multirow[b]{2}{*}{ Mean } \\
\hline & $\begin{array}{l}\text { Normal } \\
\text { furrow }\end{array}$ & $\begin{array}{c}\text { Rasied } \\
\text { bed }\end{array}$ & Mean & $\begin{array}{l}\text { Normal } \\
\text { furrow }\end{array}$ & $\begin{array}{c}\text { Rasied } \\
\text { Bed } \\
\end{array}$ & & $\begin{array}{l}\text { Normal } \\
\text { furrow }\end{array}$ & $\begin{array}{c}\text { Rasied } \\
\text { bed }\end{array}$ & Mean & $\begin{array}{l}\text { Normal } \\
\text { furrow }\end{array}$ & $\begin{array}{c}\text { Rasied } \\
\text { bed }\end{array}$ & \\
\hline & \multicolumn{12}{|c|}{$1^{\text {st }}$ Season 2010} \\
\hline I1 & $1406.33 \mathrm{a}$ & $940.00 \mathrm{~b}$ & $1173.33 \mathrm{a}$ & $1553.00 \mathrm{a}$ & $1186.67 \mathrm{c}$ & $1369.83 \mathrm{a}$ & $1.60 \mathrm{e}$ & $1.79 \mathrm{c}$ & $1.69 \mathrm{~b}$ & $2.87 \mathrm{~b}$ & $2.79 \mathrm{~b}$ & $2.83 \mathrm{a}$ \\
\hline $\mathbf{I 2}$ & $253.00 \mathrm{e}$ & $958.67 \mathrm{~b}$ & $605.83 \mathrm{~b}$ & $362.33 \mathrm{e}$ & $1217.00 \mathrm{~b}$ & $789.67 \mathrm{c}$ & $2.19 \mathrm{a}$ & $1.56 \mathrm{e}$ & $1.87 \mathrm{a}$ & $3.32 \mathrm{a}$ & $2.28 \mathrm{e}$ & $2.80 \mathrm{a}$ \\
\hline $\mathbf{I 3}$ & $383.33 \mathrm{~d}$ & $873.33 \mathrm{c}$ & $628.33 \mathrm{~b}$ & $971.00 \mathrm{~d}$ & $1242.67 \mathrm{~b}$ & $1106.83 \mathrm{~b}$ & $2.07 \mathrm{~b}$ & $1.70 \mathrm{~d}$ & $1.88 \mathrm{a}$ & $2.66 \mathrm{c}$ & $2.38 \mathrm{~d}$ & $2.52 \mathrm{~b}$ \\
\hline \multirow[t]{2}{*}{ Mean } & $680.39 \mathrm{~b}$ & $924.00 \mathrm{a}$ & & $962.11 \mathrm{~b}$ & $1215.44 \mathrm{a}$ & & $1.95 \mathrm{a}$ & $1.68 \mathrm{~b}$ & & $2.95 \mathrm{a}$ & $1.68 \mathrm{~b}$ & \\
\hline & \multicolumn{12}{|c|}{$2^{\text {nd }}$ Season 2011} \\
\hline I1 & $1276.33 \mathrm{a}$ & $445.33 \mathrm{e}$ & $860.83 \mathrm{a}$ & $1360.00 \mathrm{a}$ & $680.00 \mathrm{~b}$ & $1020.00 \mathrm{a}$ & $1.46 \mathrm{~b}$ & $1.43 \mathrm{~b}$ & $1.45 \mathrm{~b}$ & $2.00 \mathrm{~d}$ & $2.20 \mathrm{c}$ & $2.10 \mathrm{~b}$ \\
\hline I2 & $212.00 \mathrm{f}$ & $486.33 \mathrm{c}$ & $349.17 \mathrm{c}$ & $400.00 \mathrm{e}$ & $563.33 \mathrm{~d}$ & $481.67 \mathrm{~b}$ & $1.95 \mathrm{a}$ & $1.26 \mathrm{c}$ & $1.60 \mathrm{a}$ & $2.74 \mathrm{a}$ & $1.85 \mathrm{e}$ & $2.30 \mathrm{a}$ \\
\hline I3 & $565.67 \mathrm{~b}$ & $466.33 \mathrm{~d}$ & $516.00 \mathrm{~b}$ & $660.00 \mathrm{c}$ & $670.00 \mathrm{bc}$ & $665.00 \mathrm{~b}$ & $1.93 \mathrm{a}$ & $1.27 \mathrm{c}$ & $1.60 \mathrm{a}$ & $2.41 \mathrm{~b}$ & $1.86 \mathrm{e}$ & $2.14 \mathrm{~b}$ \\
\hline Mean & $684.67 \mathrm{a}$ & $466.00 \mathrm{~b}$ & & $806.67 \mathrm{a}$ & $637.78 b$ & & $1.78 \mathrm{a}$ & $1.32 \mathrm{~b}$ & & $2.39 \mathrm{a}$ & $1.97 \mathrm{~b}$ & \\
\hline
\end{tabular}

In the same cell, means followed by the same letter are not significantly different at 5\% level according to Duncan Multiple Range Test

$\mathrm{I}_{1}$ : Traditional irrigation (control), $\mathrm{I}_{2}$ : Irrigation with $0.8 \mathrm{Ep}, \mathrm{I}_{3}$ : Irrigation by using Ibrahim equation. 
Table 3. Effect of cultivation method and irrigation treatments on fresh and dry weight of Salvia officinalis L. herb (g) during the two seasons (2010 and 2011)

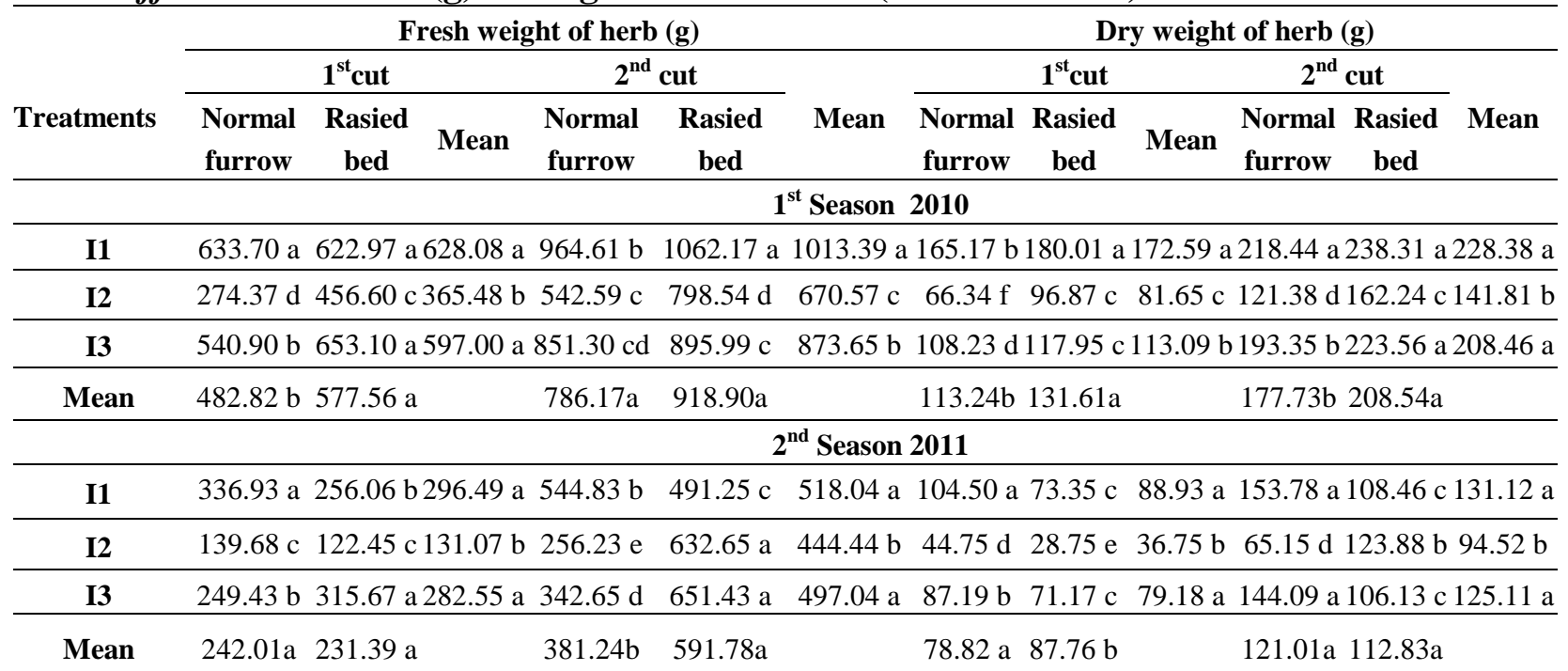

In the same cell, means followed by the same letter are not significantly different at 5\% level according to Duncan Multiple Range Test

$\mathrm{I}_{1}$ : Traditional irrigation (control), $\mathrm{I}_{2}$ : Irrigation with $0.8 \mathrm{Ep}, \mathrm{I}_{3}$ : Irrigation by using Ibrahim equation.

Table 4. Effect of cultivation method and irrigation treatments on essential oil \% and essential oil yield/plant (Liter) of Salvia officinalis L. herb during the two seasons (2010 and 2011)

\begin{tabular}{|c|c|c|c|c|c|c|c|c|c|c|c|c|}
\hline \multirow{3}{*}{ Treatments } & \multicolumn{6}{|c|}{ Essential oil\% } & \multicolumn{6}{|c|}{ Essential oil yield/plant( $L)$} \\
\hline & \multicolumn{3}{|c|}{ 1st cut } & \multicolumn{2}{|c|}{$2^{\text {nd }}$ cut } & \multirow[b]{2}{*}{ Mean } & \multicolumn{3}{|c|}{ 1st cut } & \multicolumn{2}{|c|}{$2^{\text {nd }}$ cut } & \multirow[t]{2}{*}{ Mean } \\
\hline & $\begin{array}{l}\text { Normal } \\
\text { furrow }\end{array}$ & $\begin{array}{c}\text { Rasied } \\
\text { bed }\end{array}$ & Mean & $\begin{array}{l}\text { Normal } \\
\text { furrow }\end{array}$ & $\begin{array}{c}\text { Rasied } \\
\text { bed }\end{array}$ & & $\begin{array}{l}\text { Normal } \\
\text { furrow }\end{array}$ & $\begin{array}{c}\text { Rasied } \\
\text { bed }\end{array}$ & Mean & $\begin{array}{l}\text { Normal } \\
\text { furrow }\end{array}$ & $\begin{array}{c}\text { Rasied } \\
\text { bed }\end{array}$ & \\
\hline & \multicolumn{12}{|c|}{ 1st Season 2010} \\
\hline I1 & $2.15 \mathrm{a}$ & $2.09 \mathrm{a}$ & $2.12 \mathrm{a}$ & $2.21 \mathrm{a}$ & $2.71 \mathrm{a}$ & $2.46 \mathrm{a}$ & $3.55 \mathrm{~b}$ & $3.76 \mathrm{a}$ & $3.66 \mathrm{a}$ & $4.83 \mathrm{a}$ & $5.13 \mathrm{a}$ & $4.98 \mathrm{a}$ \\
\hline $\mathbf{I 2}$ & $2.14 \mathrm{a}$ & $2.09 \mathrm{a}$ & $2.12 \mathrm{a}$ & $2.56 \mathrm{a}$ & $2.45 \mathrm{a}$ & $2.50 \mathrm{a}$ & $1.92 \mathrm{e}$ & $2.02 \mathrm{~d}$ & $1.72 \mathrm{c}$ & $3.10 \mathrm{c}$ & $3.97 \mathrm{~b}$ & $3.54 \mathrm{~b}$ \\
\hline I3 & $2.29 \mathrm{a}$ & $2.10 \mathrm{a}$ & $2.20 \mathrm{a}$ & $2.73 \mathrm{a}$ & $2.37 \mathrm{a}$ & $2.55 \mathrm{a}$ & $2.48 \mathrm{c}$ & $2.48 \mathrm{c}$ & $2.48 \mathrm{~b}$ & $5.29 \mathrm{a}$ & $5.45 \mathrm{a}$ & $5.37 \mathrm{a}$ \\
\hline \multirow[t]{2}{*}{ Mean } & $2.19 \mathrm{a}$ & $2.09 \mathrm{a}$ & & $2.50 \mathrm{a}$ & $2.51 \mathrm{a}$ & & $2.48 \mathrm{~b}$ & $2.75 \mathrm{a}$ & & $4.41 \mathrm{a}$ & $4.85 \mathrm{a}$ & \\
\hline & \multicolumn{12}{|c|}{$2^{\text {nd }}$ Season 2011} \\
\hline I1 & $2.02 \mathrm{a}$ & $2.00 \mathrm{a}$ & $2.01 \mathrm{a}$ & $2.12 \mathrm{a}$ & $2.19 \mathrm{a}$ & $2.15 \mathrm{a}$ & $2.11 \mathrm{a}$ & $1.46 \mathrm{c}$ & $1.79 \mathrm{a}$ & $3.56 \mathrm{a}$ & $2.37 \mathrm{c}$ & $2.82 \mathrm{a}$ \\
\hline I2 & $2.10 \mathrm{a}$ & $2.11 \mathrm{a}$ & $2.11 \mathrm{a}$ & $2.12 \mathrm{a}$ & $2.20 \mathrm{a}$ & $2.16 \mathrm{a}$ & $0.94 \mathrm{~d}$ & $0.61 \mathrm{e}$ & $0.78 \mathrm{~b}$ & $1.38 \mathrm{~d}$ & $2.73 \mathrm{~b}$ & $2.05 \mathrm{~b}$ \\
\hline I3 & $2.19 \mathrm{a}$ & $2.07 \mathrm{a}$ & $2.13 \mathrm{a}$ & $2.28 \mathrm{a}$ & $2.01 \mathrm{a}$ & $2.15 \mathrm{a}$ & $1.91 \mathrm{~b}$ & $1.47 \mathrm{c}$ & $1.67 \mathrm{a}$ & $3.29 \mathrm{a}$ & $2.13 \mathrm{c}$ & $2.71 \mathrm{a}$ \\
\hline Mean & $2.10 \mathrm{a}$ & $2.06 \mathrm{a}$ & & $2.17 \mathrm{a}$ & $2.13 \mathrm{a}$ & & $1.65 \mathrm{a}$ & $1.18 \mathrm{~b}$ & & $2.64 a$ & $2.41 \mathrm{a}$ & \\
\hline
\end{tabular}

In the same cell, means followed by the same letter are not significantly different at 5\% level according to Duncan Multiple Range Test

$\mathrm{I}_{1}$ : Traditional irrigation (control), $\mathrm{I}_{2}$ : Irrigation with $0.8 \mathrm{Ep}, \mathrm{I}_{3}$ : Irrigation by using Ibrahim equation.

Generally, raisedbed cultivation and traditional irrigation gave the highest values of essential oil yield/plant in the two cuts in the first season while cultivation on normal furrows and traditional irrigation $\left(\mathrm{I}_{1}\right)$ gave the highest values in the both cuts in the second seasons. These results means that traditional irrigation in this region can be the most important factor for increasing oil yield/plant. The increment of the essential oil yield/plant as a result of traditional irrigation could be explained through its effect on increasing the corresponding drug yield. Similar results were obtained by Abu-Darwish et al(2011) on Salvia officinalis and
Farahani et al. (2009) on Melissa officinalis L., they found that the highest essential oil yield was achieved under $\mathrm{T}_{3}$ (60\% field capacity) and highest essential oil $\%$ was achieved under $\mathrm{T}_{5}(20 \%$ field capacity). The essential oil yield was reduced under water stress conditions but essential oil\% increased under these conditions.

\section{Essential oil constituents:}

The main compounds and their relative percentage are shown in Table (5). Data revealed that twelve components were identified in sage oil as $\alpha$-pinene, 
comphene, $\beta$-pinene, Myrcene, 1,8 cineol, $\gamma$-terpinene, Thujone, camphor, Borneol, Bornyl acetate, Eugenol and $\beta$-caryophellene. 1,8 cineol an oxydate compound was found to be the first major compound and ranged from 10.06 to $49.95 \%$. Its maximum content was observed in the essential oil of the herb that cultivated on (raisedbed and irrigated with $0.8 \mathrm{Ep}_{2}$ ) while the minimum content was recorded with plants cultivated on (raisedbed and irrigated with using Ibrahim equation $\mathrm{I}_{3}$ ). The second main compound was identified as terpine, Myrcene in most treatment which ranged from its maximum content $(11.56 \%)$ observed in the plants cultivated on ( normal furrows and irrigated with $0.8 \mathrm{Ep}$ $\mathrm{I}_{2}$ ). Its minimum relative percent $(10.51 \%)$ on the plants cultivated on (normal furrows irrigated with Ibrahim equation $\mathrm{I}_{3}$ ) and Thujone in two treatment (normal furrows with Traditional irrigation and raisedbed irrigated with using Ibrahim equation) observed as the second main compound. The change in the components quality occurred by using different irrigation treatment and cultivation method may be due to their effect on the metabolism and on these enzyme responsible for the components synthesis. Also, water rates affected the composition of Salvia officinalis L. EO, particularly the concentrations of $\alpha$-pinene, camphene, cineol, $\alpha$ - and $\beta$ -
Thujone, bornyl acetate and $\alpha$-humulene (Corell et al., 2009). Drought stress also significantly decreased the foliar fatty acid content of Salvia officinalis L. Aerial parts. besides, moderate water deficit increased the EO yield and the content of main volatile constituents. Camphen, $\alpha$-Thujone and 1,8-cineol (Bettaieb et al., 2009). Composition of essential oil of Salvia officinalis L., significantly depended on substrate moisture and drought stress (Manukyan, 2011).

\section{Applied irrigation water $\left(\mathrm{m}^{3} / \mathrm{fed}\right)$}

Data presented in Table (6) clearly showed that the highest values were recorded through the first growing season comparing with the second one. Increasing values of applied irrigation water under the first growing season may be due to elongation growth period under conditions of this season which begins from March till August. The second reason for this result is due to increasing the temperature during summer months and hence, increasing evaporation rate from the soil surface and transpiration from plant surfaces. Consequently, increasing amount of applied water to provide plants with their water requirements to complete safely the cycle life of these plants.

Table 5. Effect of cultivation method and irrigation treatments on the percentage of the essential oil constituents of Salvia officinalis, $L$ herb. during the season of (2010)

\begin{tabular}{lcccccc}
\hline & Treatment & \multicolumn{3}{c}{ Normal furrow } & \multicolumn{4}{c}{ Rasiedbed } \\
\cline { 2 - 7 } Components & $\mathrm{I}_{1}$ & $\mathrm{I}_{2}$ & $\mathrm{I}_{3}$ & $\mathrm{I}_{1}$ & $\mathrm{I}_{2}$ & $\mathrm{I}_{3}$ \\
\hline$\alpha$-Pinene & 0.49 & 0.39 & 0.29 & 0.31 & 0.42 & 0.43 \\
Camphene & 4.84 & 5.02 & 3.56 & 3.86 & 4.43 & 4.57 \\
$\beta$-Pinene & 5.21 & 4.98 & 2.94 & 3.01 & 3.94 & 3.73 \\
Myrcene & 9.74 & 11.56 & 10.51 & 10.57 & 10.80 & 0.15 \\
1,8 Cineol & 45.52 & 46.60 & 48.53 & 48.71 & 49.95 & 10.06 \\
$\gamma$-Terpinene & 0.74 & 10.36 & 1.21 & 1.21 & 9.54 & 0.94 \\
Thujone & 12.88 & 3.64 & 10.05 & 9.99 & 1.54 & 8.84 \\
Camphor & 1.95 & 1.44 & 2.23 & 2.20 & 0.69 & 1.42 \\
B orneol & 2.97 & 1.55 & 5.14 & 5.09 & 0.96 & 3.93 \\
Bornyl acetate & 0.90 & 0.27 & 0.98 & 0.97 & 1.75 & 1.53 \\
Eugenol & 1.98 & 1.04 & 1.03 & 0.96 & 1.07 & 3.72 \\
$\beta$-caryophyllene & 4.15 & 1.36 & 3.04 & 2.91 & 3.59 & 0.24 \\
Total identified & 91.37 & 87.82 & 89.51 & 94.88 & 88.68 & 37.30 \\
Unidentified compound & 8.63 & 12.18 & 10.49 & 5.12 & 11.32 & 62.70 \\
\hline
\end{tabular}

$\mathrm{I}_{1}$ : Traditional irrigation (control), $\mathrm{I}_{2}$ : Irrigation with $0.8 \mathrm{Ep}, \mathrm{I}_{3}$ : Irrigation by using Ibrahim equation. 
Table 6. Effect of cultivation method and irrigation treatments on the average amount of seasonal applied irrigation water $\left(\mathrm{m}^{3} /\right.$ fed.) of Salvia officinalis $\mathrm{L}$. herb in the two growing seasons of 2010 and 2011

\begin{tabular}{|c|c|c|c|c|c|c|}
\hline \multirow[b]{2}{*}{$\begin{array}{l}\text { Irrigation } \\
\text { treatments }\end{array}$} & \multicolumn{2}{|c|}{$1^{\text {st }}$ growing season } & \multirow[b]{2}{*}{ Mean } & \multicolumn{2}{|c|}{$2^{\text {nd }}$ growing season } & \multirow[b]{2}{*}{ Mean } \\
\hline & $\begin{array}{l}\text { Normal } \\
\text { furrows }\end{array}$ & Raisedbed & & $\begin{array}{l}\text { Normal } \\
\text { furrows }\end{array}$ & Raisedbed & \\
\hline$I_{1}$ & 4024.7 & 2667.5 & 3346.1 & 3905.47 & 2587.24 & 3246.4 \\
\hline $\mathbf{I}_{2}$ & 3038.53 & 2265.43 & 2651.98 & 2987.14 & 2248.15 & 2617.6 \\
\hline $\mathbf{I}_{3}$ & 3745.87 & 2474.8 & 3110.3 & 3687.83 & 2365.28 & 3026.6 \\
\hline Mean & 3603.03 & 2469.24 & & 3526.81 & 2400.22 & \\
\hline
\end{tabular}

$\mathrm{I}_{1}$ : Traditional irrigation (control), $\mathrm{I}_{2}$ : Irrigation with $0.8 \mathrm{Ep}, \mathrm{I}_{3}$ : Irrigation by using Ibrahim equation.

Under all irrigation treatments, the highest mean values for seasonal applied irrigation water were recorded under cultivation on normal furrows comparing with raisedbed .Increasing the mean values of applied irrigation water under normal furrows comparing with the raisedbed might be due to increasing number of irrigation inlets, so, increasing amount of water percolation, seepage and evaporation under these conditions, therefore, plants to take their water requirements to avoid the effects of stress amount of applied irrigation water should be increased comparing with raisedbed which have few irrigation inlets. Consequently, decrease the amount of applied irrigation water. These results are in agreement with those obtained by Awad et al (2009) on sunflower .

Concerning with the effect of irrigation treatments, the highest mean values for applied irrigation water were recorded under traditional irrigation comparing with other irrigation treatments in the two growing seasons. The mean values of applied irrigation water can be descended in order traditional irrigation > irrigation by using Ibrahim's equation $>$ irrigation with $0.8 \mathrm{Ep}$. Increasing amount of applied irrigation water under traditional irrigation method comparing with the other irrigation treatments may be due to a large amount of the applied irrigation water which is wasted comparing with the other irrigation treatments, where, water applied in this case represents the actual waste water, so, application water here compensates the actual waste water. Therefore, there is no water to waste consequently the seasonal values of applied water were higher under traditional irrigation than the other irrigation treatments.

\section{Amount and percentage of saving water $\mathrm{m}^{3} / \mathrm{fed}$}

Data presented in Table (7) clearly showed that using cultivation method of raisedbed was saving a large amount of irrigation water comparing with normal cultivation method. The percentages of saving water are $33.7,25.4,33.9$ and $33.8,24.7$ and $35.9 \%$ under $I_{1}, I_{2}$ and $I_{3}$ in the first and second growing seasons, respectively. Therefore, after completeness of this study, the authors recommended that cultivation on raisedbed an effective method for saving water. Increasing the percentages of saving water under cultivation method on raisedbed comparing with the other cultivation method may be due to decreases number of irrigation inlets. So, a good control on irrigation process, consequently, increases amount of saving water.

\section{The used consumptive water $\left(\mathrm{m}^{3} /\right.$ fed. $)$}

Data in Table (8) showed that the highest mean values were recorded under normal cultivation method like practiced in the studied area. This results may be due to increasing amount of applied water under normal cultivation method, therefore increasing amount of water uptake by plants. Consequently, increasing rate of water consumptive by plants. Increasing amount of water consumption has bad effects on plants because of it encourages plants to do their best to increase vegetative growth and plants become more green and therefore will be easy to attack by pests and diseases. Also under normal cultivation method there is losing a large amount of water either by runoff, down deep percolation or by transpiration by plants. The highest mean values of the used consumptive water were recorded under irrigation treatment $I_{1}$ (traditional irrigation) in the two growing seasons comparing with the other irrigation treatments $\left(\mathrm{I}_{2}\right.$ and $\left.\mathrm{I}_{3}\right)$. The mean values of the used consumptive water for Salvia officinalis L. in the two growing seasons can be descended in order $\mathrm{I}_{1}>\mathrm{I}_{3}>\mathrm{I}_{2}$. These results are in harmony with those obtained by Younis et al. (2010) on fennel they recommended that the values of consumptive use clearly affected by irrigation treatments where the highest values were increased under $I_{1}$ (irrigation at depletion of $40 \%$ from available water).

\section{Irrigation water efficiencies $\left(\mathrm{kg} / \mathrm{m}^{3}\right)$}

The studied irrigation water efficiencies were water productivity (WP) and productivity of irrigation water (PIW). Data presented in Tables (9 and 10) clearly showed that the mean values of both WP and PIW 
Table7. Effect of cultivation method and irrigation treatments on amount and percentage of saving water of Salvia officinalis L. herb in the two growing seasons of 2010 and2011

\begin{tabular}{ccccc}
\hline \multirow{2}{*}{$\begin{array}{c}\text { Irrigation } \\
\text { treatments }\end{array}$} & \multicolumn{2}{c}{$\mathbf{1}^{\text {st }}$ growing season } & \multicolumn{2}{c}{$\mathbf{2}^{\text {nd }}$ growing season } \\
\cline { 2 - 5 } & $\begin{array}{c}\text { Amount of saving water } \\
\mathbf{m}^{\mathbf{3}} / \mathbf{f e d}\end{array}$ & $\begin{array}{c}\text { Percentage of saving } \\
\text { water } \mathbf{( \% )}\end{array}$ & $\begin{array}{c}\text { Amount of saving water } \\
\mathbf{m}^{\mathbf{3}} / \mathbf{f e d}\end{array}$ & $\begin{array}{c}\text { Percentage of saving } \\
\text { water } \mathbf{( \% )}\end{array}$ \\
\hline $\mathbf{I}_{\mathbf{1}}$ & 1357.2 & 33.7 & 1318.23 & 33.8 \\
\hline $\mathbf{I}_{\mathbf{2}}$ & 773.1 & 25.4 & 738.99 & 24.7 \\
\hline $\mathbf{I}_{\mathbf{3}}$ & 1271.07 & 33.9 & 1322.55 & 35.9 \\
\hline
\end{tabular}

$\mathrm{I}_{1}$ : Traditional irrigation (control), $\mathrm{I}_{2}$ : Irrigation with $0.8 \mathrm{Ep}, \mathrm{I}_{3}$ : Irrigation by using Ibrahim equation.

Table 8. Effect of cultivation method and irrigation treatments on consumptive use $\left(\mathrm{m}^{3} /\right.$ fed)of Salvia officinalis $\mathrm{L}$. herb in the two growing seasons of 2010and2011

\begin{tabular}{|c|c|c|c|c|c|c|}
\hline \multirow{2}{*}{$\begin{array}{l}\text { Irrigation } \\
\text { treatments }\end{array}$} & \multicolumn{2}{|c|}{$\mathbf{1}^{\text {st }}$ growing season } & \multirow[b]{2}{*}{ Mean } & \multicolumn{2}{|c|}{$2^{\text {nd }}$ growing season } & \multirow[b]{2}{*}{ Mean } \\
\hline & $\begin{array}{l}\text { Normal } \\
\text { furrows }\end{array}$ & Raisedbed & & $\begin{array}{l}\text { Normal } \\
\text { furrows }\end{array}$ & Raisedbed & \\
\hline $\mathbf{I}_{1}$ & 2616.06 & 1800.62 & 2208.34 & 2343.28 & 2118.07 & 2230.68 \\
\hline $\mathbf{I}_{2}$ & 2035.82 & 1695.18 & 1865.50 & 1927.62 & 1528.74 & 1728.18 \\
\hline $\mathbf{I}_{3}$ & 2547.19 & 1732.36 & 2139.78 & 2008.62 & 1642.82 & 1825.72 \\
\hline Mean & 2399.69 & 1742.72 & & 2093.17 & 1763.21 & \\
\hline
\end{tabular}

$\mathrm{I}_{1}$ : Traditional irrigation (control), $\mathrm{I}_{2}$ : Irrigation with $0.8 \mathrm{Ep}, \mathrm{I}_{3}$ : Irrigation by using Ibrahim equation.

Table 9.Effect of cultivation method and irrigation treatments on water productivity (WP) $\mathrm{kg} / \mathrm{m}^{3}$ of Salvia officinalis $\mathrm{L}$. herb in the two growing seasons (2010and2011)

\begin{tabular}{|c|c|c|c|c|c|c|}
\hline \multirow[b]{2}{*}{$\begin{array}{l}\text { Irrigation } \\
\text { treatments }\end{array}$} & \multicolumn{2}{|c|}{$1^{\text {st }}$ growing season } & \multirow[b]{2}{*}{ Mean } & \multicolumn{2}{|c|}{$2^{\text {nd }}$ growing season } & \multirow[b]{2}{*}{ Mean } \\
\hline & $\begin{array}{l}\text { Normal } \\
\text { furrows }\end{array}$ & Raisedbed & & $\begin{array}{l}\text { Normal } \\
\text { furrows }\end{array}$ & Raisedbed & \\
\hline $\mathbf{I}_{1}$ & 1.47 & 2.32 & 1.90 & 1.15 & 2.16 & 1.66 \\
\hline $\mathbf{I}_{2}$ & 0.92 & 1.53 & 1.23 & 0.57 & 1.00 & 0.79 \\
\hline $\mathbf{I}_{3}$ & 1.18 & 1.97 & 1.58 & 1.10 & 1.72 & 1.41 \\
\hline Mean & 1.19 & 1.94 & & 0.94 & 1.62 & \\
\hline
\end{tabular}

$\mathrm{I}_{1}$ : Traditional irrigation (control), $\mathrm{I}_{2}$ : Irrigation with $0.8 \mathrm{Ep}, \mathrm{I}_{3}$ : Irrigation by using Ibrahim equation.

Table 10. Effect of cultivation method and irrigation treatments on water productivity of irrigation water (WIP) $\mathrm{kg} / \mathrm{m}^{3}$ of Salvia officinalis $\mathrm{L}$. herb in the two growing seasons (2010and2011)

\begin{tabular}{|c|c|c|c|c|c|c|}
\hline \multirow[b]{2}{*}{$\begin{array}{l}\text { Irrigation } \\
\text { treatments }\end{array}$} & \multicolumn{2}{|c|}{$1^{\text {st }}$ growing season } & \multirow[b]{2}{*}{ Mean } & \multicolumn{2}{|c|}{$2^{\text {nd }}$ growing season } & \multirow[b]{2}{*}{ Mean } \\
\hline & $\begin{array}{l}\text { Normal } \\
\text { furrows }\end{array}$ & Raisedbed & & $\begin{array}{l}\text { Normal } \\
\text { furrows }\end{array}$ & Raisedbed & \\
\hline $\mathbf{I}_{1}$ & 0.95 & 1.57 & 1.26 & 0.66 & 1.24 & 0.95 \\
\hline $\mathbf{I}_{2}$ & 0.62 & 1.14 & 0.88 & 0.37 & 0.58 & 0.48 \\
\hline $\mathbf{I}_{3}$ & 0.81 & 1.38 & 1.10 & 0.63 & 1.20 & 0.92 \\
\hline Mean & 0.79 & 1.36 & 1.08 & 0.55 & 1.01 & 0.78 \\
\hline
\end{tabular}

$\mathrm{I}_{1}$ : Traditional irrigation (control), $\mathrm{I}_{2}$ : Irrigation with $0.8 \mathrm{Ep}, \mathrm{I}_{3}$ : Irrigation by using Ibrahim equation.

were affected by both cultivation method and irrigation treatments in the two growing seasons. The data illustrated that the values of WP were higher than the values of PIW in the two growing seasons. Increasing the mean values of WP comparing with those of WIP may be due to decreasing the values of the used consumptive water in comparison with the values of applied water.

Also, data cleared that the highest mean values were recorded under cultivation on raisedbed comparing with normal cultivation in the two growing seasons. The same trend was observed for PIW but the mean values were less than obtained for WP in the two seasons. 
Data in the same Tables declared that the highest mean values for the two studied irrigation efficiencies (WP and PIW) were recorded under irrigation treatment $\left(\mathrm{I}_{1}\right)$ comparing with the other irrigation treatments $\mathrm{I}_{2}$ and $\mathrm{I}_{3}$ in the two growing seasons. Generally, the mean values of both WP and PIW can be descended in order in the two growing seasons $\mathrm{I}_{1}>\mathrm{I}_{3}>\mathrm{I}_{2}$. These results are in harmony with those obtained by El-Abd et al (2012) on Citrus sinensis, Osbeck. They illustrated that values of water productivity were higher than those of productivity of irrigation water and the highest values for the both studied parameters were recorded under $\mathrm{I}_{2}$ (giving 8 irrigations through the whole growing season).

\section{CONCLUSION}

This investigation showed that cultivation on raisedbed in the two sides were suitable for Salvia officinalis, L in heavy clay soils which increased the most studied parameters of the plant and saving a large amount of water reached to $1357.20 \mathrm{~m}^{3} / \mathrm{fed}$ and irrigated with traditional irrigation with applied water reached to $3346.1 \mathrm{~m}^{3} / \mathrm{fed}$.

\section{REFERENCES}

Abu-Darwish, M.S.; A.H. Al-Fraihat, S.Y.A. Al-Dalain, F.Y. Afifi and J.A. Al-Tabbal (2011). Determination of essential oils and heavy metals accumulation on Salvia officinalis L. cultivated in three intra-row spacing in AshShoubak, Jordan, Int. J. Agric. Biol., 13: 981-985.

Awad, M.M. .;E.A. Moursi and F.Sh.Sedeek(2009)Effect of missing irrigation, mineral and biofertilization on sunflower in north nile delta region. J.Agric.Sci.Mansoura. Univ.,34(10):10263-10279.

Ahmetozturk, Ali Ulukara, Arif Ipek and Bilal Gurbuz (2004). Effect of stress and water deficit on plant growth and essential oil content of lemon balm (Melissa officinalis L.). Pak. J. Bot., 36(4): 787-792.

Ali, M.H.; M.R. Hoque; A.A. Hassan and A. Khair (2007). Effects of deficit irrigation on yield, water productivity, and economic returns of wheat. Agricultural Water Management 92(3): 151-161.

Al-Qura'n, S. (2009). Ethnopharmacological survey of wild medicinal plants in showback. Jordan J. Ethnopharmacol., 123: 45-50.

Bannayan, M.; Nadjafi, F.; Azizi, M.; Tabrizi, L. Tastgoo, M.; (2008). Yield and seed quality of Plantago ovata and Nigella sativa under different irrigation treatments. $2^{\text {nd }}$ Crops Prod. 27: 11-16.

Battaieb, I.; N. Zakhama, W.A. Wannes; M.E. Kchouk and B. Marzouk (2009). Wter deficit effect on Salvia officinalis fatty acids and essential oils composition. Scientia. Hort. 120(2): 271-275.

Black, C.A.; D.D. Evans, L.E. Ensmigger, J.L. White and F.E. Clark (1965). Methods of soil analysis. Amer. Soc. Agron., Inc., Madison, Wisconsin, USA.

British Parmacopoeia (1963). Determination of volatile oil in drugs. The Pharmaceutical Press, London.
Corell, M.; M. Castillo, Gareia and P. Cermeno (2009). Effect of the deficit watering in the production and quality of the essential oil, in the cultivation of Salvia officinalis L. Acta Horticulturae, 62(1): 281-288.

Early, A.C. (1975). Irrigation scheduling for wheat in the Punjab. CENTO Scientific Programme on the optimum use of water in agriculture. Report No. 17, Lyallpur, Pakistan, March, 3-5: 115-127.

El-Abd, A. A.; E. A. Moursi and M. A. Gabr (2012). Effect of irrigation water regime on navel orange yield ,fruit quality and some water relations in the north middle Nile Delta Region. J. Plant Production, Mansoura Univ., 3(6): 10491061.

El-Boraie, F.M. and A.M. Gaber (2009). Maximizing water use efficiency by Roselle at south-east of Egypt. Journal of Applied Sciences Research, 5(1): 21-32.

El-Boraie, F.M.; A.M. Gaber, and G. Abdel-Rahman (2009). Optimizing irrigation schedule to maximize water use efficiency of Hibiscus sabdariffa under Shalatien conditions. World Journal of Agricultural Science, 5(4): 504-514.

El-Mekawy, M.A.M. (2009). Effect of irrigation intervals and biofertilization on growth and oil yield of Thymus capitatus L. under El-Arish conditions. J. Agric. Res. Kafr El-Sheikh Univ., 35(4): 1050-1068.

El-Quosy, D. (1998). The challenge for water in the twenty first century. The Egyptian experience. Arab Water 98 Ministry of Water Resources and Irrigation (MWRI) April 26-29, Cairo, Egypt.

Farahani, H.A.; Valadabadi, S.A.; Daneshian, J. and Khalvati, M.A. (2009). Evaluation changing of essential oil of balm (Melissa officinalis L.) under water deficit stress conditions. J. Med. Plants Res. 3(5): 329-333.

Ghaly, N. G ;F. R. Moussa and S .I . Younis (2003) Response of Carum Carvi ,L. fruit and essential oil yield to sowing method, planting distances and some micronutrient application methods .J .Agric .Sci .Mansoura Univ.,28 (9):6865 -6877

Hansen, V.W.; O.W. Israelsen and G.E. Stringharm (1979). Irrigation principles and practices. $9^{\text {th }}$ ed., John Willey and Sons Inc., New York, USA.

Huxley, A.J. (1992). New Royal Horticultural Society Dictionary of Gardening. 4 Vols. Macmillan Press, London, pp. 3-240.

Ibrahim, M.A.M. (1981). Evaluation of different methods for calculating potential evapotranspiration in North Delta region. Ph.D. Thesis, Soil \& Water Sci., Alex. Univ.

Isrealsen, D.W. and V.E. Hansen (1962). Flow of water into and through soil. Irrigation Principles and Practices. $3^{\text {rd }}$ Edition. John Wiley and Sons Inc., New York, N.Y., U.S.A.

James, L.G. (1988). Principles of farm irrigation system design. John Willey \& Sons (ed.), New York, pp. 543.

Katsoules, N.; C. Kittas; G. Dimokas and C. Lykas (2006). Effect of irrigation frequency on rose flower production and quality. Biosyst. Eng. 93(2): 237-244.

Khattab, M.; Ola El-Shennawy; M. Mostafa and Naglaa Gomaa (2002). Effect of some soil conditions and irrigation rates on the growth and flowering of Salvia splendens plants. Alex. J. Agric. Res., 48(2): 163-172. 
Khazaie, H.R.; F. Nadjafi, and M. Bannayan (2008). Effect of irrigation frequency and planting density on herbage biomass and oil production of Thyme (Thymus vulgaris) and hyssop (Hyssopus officinalis). Industrial Crops and Products, 27: 315-321.

Klute, A. (1986). Water retention: Laboratory methods. In: A. Koute (ed.), Methods of soil Analysis, Part $1.2^{\text {nd }}$ ed. Agron. Monogr. 9, ASA, Madison, W1 U.S.A., pp. 635 660.

Manukan, A. (2011). Effect of growing factors on productivity and quality of Lemon catmin, Lemon balm and sage under soil less greenhouse production. I. Drought stress. Med. Aromatic. Plant Sci. and Bio. 5(2): 119-125.

Nadjafi, F.; Bannayan, M.; Rastgoo, M.; Tabrizi, L. (2006). Seed germination and dormancy breaking techniques for Ferula gummosa and Teucrium polium). Arid Environ. 64: 542-547.

Robert, A. (1995). Identification of essential oils by gas chromatography mass spectrometry. Allard Pub., USA.
Singh, M.; S. Shama and S. Ramesh (2002). Herbage, oil yield and oil quality of patchouli (Pogastemon cablin (Blanco) Benth.) influenced by irrigation, organic mulch and nitrogen application in semi-arid tropical climate. Industrial Crops and Prod. 16: 101-107.

Snedecor, G.W. and W.G. Cochran (1967). Statistical Methods. $6^{\text {th }}$ ed. Iowa State Univ., USA.

Steel, R.G. and J.H. Torrie (1980). Principles and Procedures of Statistics, McGraw Hill Book Company Inc., New York, N.L.S.D., London.

Vomocil, J.A. (1957). Measurements of soil bulk density and penetrability. A Review of Methods Adv. Agric., 9, New York, London Edited by Norman, A.G., pp. 159-176.

Younis, S.I.; Nahed, M. Rashed and E.A. Moursi (2010). Effect of water stress and potassium fertilizer on the growth, yield and composition of essential oil of fennel plant. J. Plant Production, Mansoura Univ., 1(7): 931-946.

\section{الملخص العربي}

\section{تأثير طريقة الزراعة ونظام الرى على النمو ومحصول الزيت لنباتات المريمية وبعض العلاقات المائية فى الأراضى الطينية الثقيلة ناهد مصطفى راشد، السيد ابو الفتوح مرسى}

$$
\begin{aligned}
& \text { كما وجد ان الرى التقليدى ادى لزيادة انتاجية العشب والمحصول } \\
& \text { والزيت العطرى كما ان التفاعل بين طريقة الزراعة على مصاطب والرى } \\
& \text { التقليدى أعطى أفضل النتائج. وبالنسبة لمكونات الزيت العطرى وجد } \\
& \text { أن السينيول هو المكون الرئيسى يليه الميرسين والثوجون.وبالنسبة لقيم } \\
& \text { الماء المضاف وقيم الاستهلاك المائى وانتاجية الملاء وانتاجية مياة الرى } \\
& \text { فقد تأثرت بصورة واضحة بطريقة الزراعة ومعاملات الرى لذلك يمكن. } \\
& \text { التوصية بزراعة المريمية على مصاطب على الريشتين والرى التقليدى }
\end{aligned}
$$

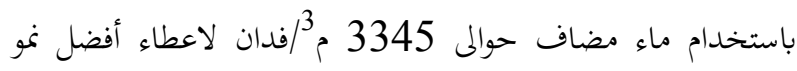

$$
\begin{aligned}
& \text { ومحصول الزيت لنبات المريمية المنزرعة بالاراضى الطينية الثقيلة. }
\end{aligned}
$$

$$
\begin{aligned}
& \text { أجريت بتربتان حقليتان في مزرعة مططة البحوث الزراعية بسخا } \\
& \text { خلال موسمى النمو 2010، 2011لدراسة تأثير طريقة الزراعة وهى } \\
& \text { الزراعة على خطوط والزراعة على مصاطب على الريشتين ومعاملات } \\
& \text { الرى هى الرى التقليدى والرى باستخدام 0.8من وعاء البخر والرى } \\
& \text { باستخدام معادلة ابراهيم وذلك على النمو ومحصول الزيت وبعض } \\
& \text { العلاقات المائية لنبات المريمية. } \\
& \text { وقد أوضحت النتائج أن الزراعة على المصاطب قد أعطت زيادة } \\
& \text { في طول النبات وعدد الأفرع وعدد الأوراق للنبات على حساب نسبة } \\
& \text { الاوراق للأفرع وزيادة المحصول الطازج والجاف للنبات وزيادة نسبة }
\end{aligned}
$$

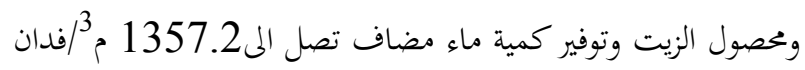

$$
\begin{aligned}
& \text { مقارنة بالزراعة على خطوط وذلك في الحشتين خلال الموسمين. }
\end{aligned}
$$

